\title{
Commentary
}

\section{The metabolic syndrome in China}

\author{
Bernard M. Y. Cheung \\ Department of Medicine, University of Hong Kong, Queen Mary Hospital, Hong Kong
}

The metabolic syndrome is a cluster of abnormalities including obesity, dyslipidaemia, abnormal blood glucose and raised blood pressure [1]. Reaven drew attention to this syndrome, which he called syndrome $\mathrm{X}[2]$. Its importance is increasingly recognized in recent years because it predicts cardiovascular disease and the development of diabetes [3-6]. The metabolic syndrome is heterogeneous, so no definition is entirely satisfactory. The World Health Organization (WHO) proposed a definition in 1998 [7]. In 2001, the third report of the National Cholesterol Education Program Expert Panel on Detection, Evaluation, and Treatment of High Blood Cholesterol in Adults (Adult Treatment Panel) (NCEPATPIII) defined it in terms of waist circumference, blood pressure and blood biochemistry [8, 9]. In 2005, the International Diabetes Federation (IDF) made abdominal obesity a prerequisite in the definition [10]. The WHO definition is difficult to embrace because glucose tolerance tests and measurement of insulin sensitivity are seldom performed in clinical practice. In the USA, the revised NCEP and the IDF definitions are quite consistent, with $92.9 \%$ agreement [11]. In other ethnic populations, such as Asians, the new ethnic-specific waist circumference criteria may slightly increase the prevalence of the metabolic syndrome [12].

The metabolic syndrome has become quite controversial $[13,14]$. Many cases of hypertension are unrelated to it. Its diagnosis in a diabetic is not clinically useful, because diabetes is a well-defined disease that is best treated by clinicians with a special interest in diabetes and with support from specialized centres. The metabolic syndrome can be perceived as having two stages. In the first stage, rather than drug treatment, lifestyle changes are indicated. The concept of the metabolic syndrome is useful here because weight control and regular exercise may prevent or delay the onset of hyper- tension and diabetes. In stage two, the person has an abnormality in one or more components of the metabolic syndrome that requires specific drug treatment, such as antihypertensive, antidiabetic or lipid-lowering agents. This may arise not only because of an extremely abnormal single risk factor, but also because of a high overall cardiovascular risk. This is also a stage at which referral for specialist care should be considered.

China has a population of 1.3 billion. Its economy has grown rapidly and continuously in the last two decades. In a country that had witnessed war, revolution, famine and rationing, food is now readily available and sold in open markets. It is easier to adjust to having more money than having more food. Babies born in an era of famine may be metabolically adapted to it and more prone to develop the metabolic syndrome when food is abundant. Thus, it may be construed that China is undergoing a large-scale natural experiment in which the 'predictive adaptive responses' of the population to a nutritionally poor early environment is counter-productive for health, despite and possibly due to increased prosperity [15].

In a study of a large professional population in Beijing, the prevalence of the metabolic syndrome was $13.2 \%$ [16]. In a nationally representative sample of 15540 Chinese adults aged 35-74 years in 2000-2001, the age-standardized prevalence of the metabolic syndrome, defined according to NCEP guidelines, was $9.8 \%$ in men and $17.8 \%$ in women [17]. The age-standardized prevalence for being overweight [body mass index $(B M I)=25$ ] was $26.9 \%$ in men and $31.1 \%$ in women The prevalence of the metabolic syndrome and being overweight was higher in northern than in southern China and in urban than rural residents. The metabolic syndrome is common in the elderly, mainly because of the rise in prevalence of hypertension and diabetes with age. China is facing the problem of an ageing population. 
The effort to control population growth, e.g. through the one child policy on the one hand and increasing longevity on the other, results in a shift in the age distribution of the population. This will increase the prevalence of the metabolic syndrome and the incidence of cardiovascular disease. The increased prevalence of the metabolic syndrome is also seen in other Chinese populations and other parts of Asia, currently being $11 \%$ in Korea and $29 \%$ in India [18-21]. Such figures are becoming comparable to those in the USA [22, 23].

In Asian populations, the increases in Type 2 diabetes and the metabolic syndrome are thought to be due to increasing obesity. In caucasians, a BMI of $>30$ is obese and that of $>25$ is overweight. Many Asians may not look obese and have BMIs that fall within the normal range for caucasians, but it is recognized that many Asian populations have a greater tendency to develop diabetes at modest levels of BMI and waist circumference [24-26]. Thus, in Asia, a lower cut-off for overweight is used [27-29]. However, BMI does not reflect adiposity, nor does it describe the distribution of fat. The waist circumference might be a better measure of abdominal or central obesity. There is some debate as to whether or not the waist-hip ratio is better than the waist circumference alone in predicting cardiovascular risk [30]. In Chinese, the waist circumference adds additional risk information to that of BMI and may therefore enhance cardiovascular risk stratification [31].

Abdominal obesity has been postulated as the leading modifiable cause of cardiovascular disease in Asia [32]. Obesity is at the centre of the metabolic syndrome and needs to be treated as seriously as hypertension and diabetes. Treatment of obesity not only reduces body weight, but also waist circumference, body fat percentage, blood pressure, plasma glucose and lipid levels [33]. Lifestyle changes have been shown to prevent diabetes [34]. The United States Food and Drug Administration has currently approved five drugs for the treatment of obesity, orlistat and sibutramine being the most widely used. Rimonabant, a selective cannabinoid-1 receptor blocker, has been shown to reduce body weight and improve cardiovascular risk factors in obese patients [35]. As people cannot change their dietary habits easily, drugs might be needed. An emerging problem in China is the adulteration of health food with pharmaceuticals. As natural herbs are probably not very effective in weight control, some brands of slimming pills sold as health foods contain sibutramine, ephedrine, phentermine and even 'fen-phen' (the combination of fenfluramine and phentermine now banned because fenfluramine can cause valvular heart disease) [36] and find their way to Hong Kong and probably other parts of the world.
To combat the epidemic of obesity, it may be more important to change dietary habits at the community level, to encourage the consumption of foods that are low in glycaemic load [37] and index, and high in fibre. Glycaemic index is a measure of how much the food raises the blood glucose compared with glucose itself, which has a glycaemic index of 100 by definition. Foods with high glycaemic indices cause a high blood glucose peak, stimulate insulin secretion, which then causes hunger a few hours later. Polished rice, the staple food in southern China, is low in fibre and has a glycaemic index ranging from 50 to 94 [38]. Congee, popularly believed to be a healthy food item, can cause a particularly high peak in plasma glucose [39]. The Chinese diet has a low fat content [40], yet Chinese populations have a very high incidence of impaired glucose tolerance [18]. In the Hong Kong Cardiovascular Risk Factor Prevalence Survey-2 cohort, one-third of those over the age of 65 years had diabetes (unpublished data). A nutritional survey of the same cohort showed that the intake of rice and pasta was high in diabetics of normal body weight [41]. Thus, in much of Asia obesity and insulin resistance are not due to excess fat in the diet but to the imbibing of carbohydrates in excess of energy needs. The Harvard Healthy Eating Pyramid puts rice at the top [42] whilst the old Food Guide Pyramid put rice at the base [43]. We are now advised to eat brown and wild rice instead of white rice [44], but nearly all Chinese restaurants still serve white rice only.

The WHO now recommends moderate physical activity on most days of the week [45]. Visitors to China in recent years would be surprised to find that bicycles have been replaced by motor cars. China is now a major car manufacturing country and exports cars to Europe. The drop in physical activity in Chinese is a concern and, although it may be a sign of growing affluence, it also presages the metabolic syndrome and cardiovascular disease.

China is in a position to halt or reverse the increase in the metabolic syndrome. The government is famous for getting things done. China may want to catch up with Britain and America in many things, but hopefully not obesity or the metabolic syndrome.

\section{Conflict of interest}

None declared.

\section{References}

1 Meigs JB. Invited commentary: insulin resistance syndrome? Syndrome X? Multiple metabolic syndrome? A syndrome at all? Factor analysis reveals patterns in the fabric of correlated 
metabolic risk factors. Am J Epidemiol 2000; 152: 908-11 (Review).

2 Reaven GM. Banting Lecture. Role of insulin resistance in human disease. Diabetes 1988; 37: 1595-607.

3 Wilson PW, Kannel WB, Silbershatz H, D'Agostino RB. Clustering of metabolic factors and coronary heart disease. Arch Intern Med 1999; 159: 1104-9.

4 Isomaa B, Almgren P, Tuomi T, Forsen B, Lahti K, Nissen M, Taskinen MR, Groop L. Cardiovascular morbidity and mortality associated with the metabolic syndrome. Diabetes Care 2001; 24: 683-9.

5 Trevisan M, Liu J, Bahsas FB, Menotti A. Syndrome X and mortality: a population-based study: Risk Factor and Life Expectancy Research Group. Am J Epidemiol 1998; 148: 958-66.

6 Haffner SM, Valdez RA, Hazuda HP, Mitchell BD, Morales PA, Stern MP. Prospective analysis of the insulin-resistance syndrome (syndrome X). Diabetes 1992; 41: 715-22.

7 Alberti KG, Zimmet PZ. Definition, diagnosis and classification of diabetes mellitus and its complications. Part 1. Diagnosis and classification of diabetes mellitus, provisional report of a WHO consultation. Diabet Med 1998; 15: 539-53.

8 National Institutes of Health. Third Report of the National Cholesterol Education Program Expert Panel on Detection, Evaluation, and Treatment of High Blood Cholesterol in Adults (Adult Treatment Panel III). Executive Summary. NIH Publ. no. 01 3670. Bethesda, MD: National Institutes of Health, National Heart, Lung and Blood Institute 2001.

9 Grundy SM, Brewer HB Jr, Cleeman JI, Smith SC Jr, Lenfant C; American Heart Association; National Heart, Lung, and Blood Institute. Definition of metabolic syndrome: Report of the National Heart, Lung, and Blood Institute/American Heart Association conference on scientific issues related to definition. Circulation 2004; 109: 433-8.

10 Alberti KG, Zimmet P, Shaw J; IDF Epidemiology Task Force Consensus Group. The metabolic syndrome-a new worldwide definition. Lancet 2005; 366 (9491): 1059-62.

11 Ford ES. Prevalence of the metabolic syndrome defined by the International Diabetes Federation among adults in the US. Diabetes Care 2005; 28: 2745-9.

12 Ko GT, Cockram CS, Chow CC, Yeung VT, Chan WB, So WY, Chan NN, Chan JC. Metabolic syndrome by the international diabetes federation definition in Hong Kong Chinese. Diabetes Res Clin Pract 2006; [Epub ahead of print].

13 Gale EA. The myth of the metabolic syndrome. Diabetologia 2005; 48: 1679-83.

14 Kahn R, Buse J, Ferrannini E, Stern M. The metabolic syndrome: time for a critical appraisal: joint statement from the American Diabetes Association and the European Association for the Study of Diabetes. Diabetes Care 2005; 28: 2289-304.

15 Gluckman PD, Hanson MA. Living with the past: evolution, development, and patterns of disease. Science 2004; 305 (5691): 1733-6.

$16 \mathrm{Li} Z \mathrm{ZY}, \mathrm{Xu} \mathrm{GB}$, Xia TA. Prevalence rate of metabolic syndrome and dyslipidemia in a large professional population in Beijing. Atherosclerosis 2006; 184: 188-92.

17 Gu D, Reynolds K, Wu X, Chen J, Duan X, Reynolds RF, Whelton $\mathrm{PK}, \mathrm{He}$ J. Prevalence of the metabolic syndrome and overweight among adults in China. Lancet 2005; 365: 1398-405.

18 Gu D, Reynolds K, Duan X, Xin X, Chen J, Wu X, Mo J, Whelton PK, He J; InterASIA Collaborative Group. Prevalence of diabetes and impaired fasting glucose in the Chinese adult population. International Collaborative Study of Cardiovascular Disease in Asia (InterASIA). Diabetologia 2003; 46: 1190-8.

19 Zimmet P, Alberti KGMM, Shaw J. Global and societal implications of the diabetes epidemic. Nature 2001; 414: 782-7.

20 Lee WY, Park JS, Noh SY, Rhee EJ, Kim SW, Zimmet PZ. Prevalence of the metabolic syndrome among 40,698 Korean metropolitan subjects. Diabetes Res Clin Pract 2004; 65: 143-9.

21 Thomas GN, Ho SY, Janus ED, Lam KS, Hedley AJ, Lam TH for the Hong Kong Cardiovascular Risk Factor Prevalence Study Steering Committee. The US National Cholesterol Education Programme Adult Treatment Panel III (NCEP ATP III) prevalence of the metabolic syndrome in a Chinese population. Diabetes Res Clin Pract 2005; 67: 251-7.

22 Ford ES, Giles WH, Dietz WH. Prevalence of the metabolic syndrome among US adults. Findings from the Third National Health and Nutrition Examination Survey. JAMA 2002; 287: 3569.

23 Patel A, Huang KC, Janus ED, Gill T, Neal B, Suriyawongpaisal $P$, Wong E, Woodward M, Stolk RP. Is a single definition of the metabolic syndrome appropriate? - A comparative study of the USA and Asia. Atherosclerosis 2006; 184: 225-32.

24 Zhou BF. Effect of body mass index on all-cause mortality and incidence of cardiovascular diseases - report for meta-analysis of prospective studies open optimal cut-off points of body mass index in Chinese adults. Biomed Environ Sci 2002; 15: 245-52.

25 Moon OR, Kim NS, Jang SM, Yoon TH, Kim SO. The relationship between body mass index and the prevalence of obesity-related diseases based on the 1995 National Health Interview Survey in Korea. Obes Res 2002; 3: 191-6.

26 Kim Y, Suh YK, Choi H. BMI and metabolic disorders in South Korean adults: 1998 Korea National Health and Nutrition Survey. Obes Res 2004; 12: 445-53.

27 WHO Expert Consultation. Appropriate body-mass index for Asian populations and its implications for policy and intervention strategies. Lancet 2004; 363 (9403): 157-63.

28 Lin WY, Lee LT, Chen CY, Lo H, Hsia HH, Liu IL, Lin RS, Shau WY, Huang KC. Optimal cut-off values for obesity: using simple anthropometric indices to predict cardiovascular risk factors in Taiwan. Int J Obes Relat Metab Disord 2002; 26: 1232-8.

29 Tan C-E, Ma sm Wai D, Chew S-K, Tai E-S. Can we apply the National Cholesterol Education Program Adult Treatment Panel definition of the metabolic syndrome to Asians? Diabetes Care 2004; 27: 1182-6.

30 Yusuf S, Hawken S, Ounpuu S, Bautista L, Franzosi MG, Commerford P, Lang CC, Rumboldt Z, Onen CL, Lisheng L, Tanomsup S, Wangai P Jr, Razak F, Sharma AM, Anand SS, 
INTERHEART Study Investigators. Obesity and the risk of myocardial infarction in 27,000 participants from 52 countries: a case-control study. Lancet 2005; 366 (9497): 1640-9.

31 Wildman RP, Gu D, Reynolds K, Duan X, Wu X, He J. Are waist circumference and body mass index independently associated with cardiovascular disease risk in Chinese adults? Am J Clin Nutr, 2005; 82: 1195-202.

32 Cheung BM. The cardiovascular continuum in Asia-a new paradigm for the metabolic syndrome. J Cardiovasc Pharmacol 2005; 46: 125-9.

33 Tong PC, Lee ZS, Sea MM, Chow CC, Ko GT, Chan WB, So WY, Ma RC, Ozaki R, Woo J, Cockram CS, Chan JC. The effect of orlistatinduced weight loss, without concomitant hypocaloric diet, on cardiovascular risk factors and insulin sensitivity in young obese Chinese subjects with or without type 2 diabetes. Arch Intern Med 2002; 162: 2428-35.

34 Tuomilehto J, Lindstrom J, Eriksson JG, Valle TT, Hamalainen H, Ilanne-Parikka P, Keinanen-Kiukaanniemi S, Laakso M, Louheranta A, Rastas M, Salminen V, Uusitupa M; Finnish Diabetes Prevention Study Group. Prevention of type 2 diabetes mellitus by changes in lifestyle among subjects with impaired glucose tolerance. $\mathrm{N}$ Engl J Med 2001; 344: 1343-50.

35 Despres JP, Golay A, Sjostrom L. Rimonabant in Obesity-Lipids Study Group. Effects of rimonabant on metabolic risk factors in overweight patients with dyslipidemia. N Engl J Med 2005; 353: 2121-34.

36 Shively BK, Roldan CA, Gill EA, Najarian T, Loar SB. Prevalence and determinants of valvulopathy in patients treated with dexfenfluramine. Circulation 1999; 100: 2161-7.

37 Brand-Miller JC, Holt SH, Pawlak DB, McMillan J. Glycemic index and obesity. Am J Clin Nutr 2002; 76: 281S-5S.
38 Foster-Powell K, Miller JB. International tables of glycemic index. Am J Clin Nutr 1995; 62: 871S-93S.

39 Chan EM, Cheng WM, Tiu SC, Wong LL. Postprandial glucose response to Chinese foods in patients with type 2 diabetes. J Am Diet Assoc 2004; 104: 1854-8.

40 Woo J, Woo KS, Leung SS, Chook P, Liu B, Ip R, Ho SC, Chan SW, Feng IZ, Celermajer DS. The Mediterranean score of dietary habits in Chinese populations in four different geographical areas. Eur J Clin Nutr 2001; 55: 215-20.

41 Woo J, Ho SC, Sham A, Sea MM, Lam KS, Lam TH, Janus ED. Diet and glucose tolerance in a Chinese population. Eur J Clin Nutr 2003; 57: 523-30.

42 Willett WC. Eat, Drink, and Be Healthy: The Harvard Medical School Guide to Healthy Eating. New York: Simon \& Schuster 2001.

43 http://www.usda.gov/cnpp/pyrabklt.pdf Last accessed 18 January 2006.

44 http://www.mypyramid.gov Last accessed 18 January 2006.

45 Global Strategy on Diet, Physical Activity and Health. WHO resolution WHA5 1. 17. 57th World Health Assembly 22 May 2004.

\section{Received}

1 February 2006

Accepted

20 February 2006

Published OnlineEarly

21 April 2006

\section{Correspondence}

Dr B. M. Y. Cheung, Department of Medicine, University of Hong Kong, Queen Mary Hospital Pokfulam, Hong Kong. Tel: + 8522855 4768;

Fax: + 8522904 9443; E-mail: mycheung@hkucc.hku.hk 